\title{
Copper-Silver Deposits of the Revett Formation, Montana and Idaho-Origin and Resource Potential
}

he Revett Formation of northern
Idaho and western Montana con-
tains major stratabound copper-silver
deposits near Troy, Rock Creek, and
Rock Lake, Montana. To help the U.S.
Forest Service (USFS) meet its goal of
integrating geoscience information
into the land-planning process, U.S.
Geological Survey (USGS) scientists
recently completed a compilation of
regional stratigraphy and mineralogy
of the Revett Formation and a mineral-
resource assessment of Revett-type
copper-silver deposits. The USGS
assessment indicates that a large area
of USFS-administered land in north-
western Montana and northern Idaho
may contain significant undiscovered
Revett-type copper-silver deposits.

The western Montana copper belt, which extends from northwestern Montana into northern Idaho, contains several large stratabound (confined to a single stratigraphic unit) copper-silver deposits in fine- to medium-grained quartzites (metamorphosed quartz sandstone) of the Revett Formation. A recent U.S. Geological Survey (USGS) assessment indicates that a large area of U.S. Forest Service (USFS)-administered land in northwestern Montana and northern Idaho may contain significant undiscovered Revett-type copper-silver deposits.

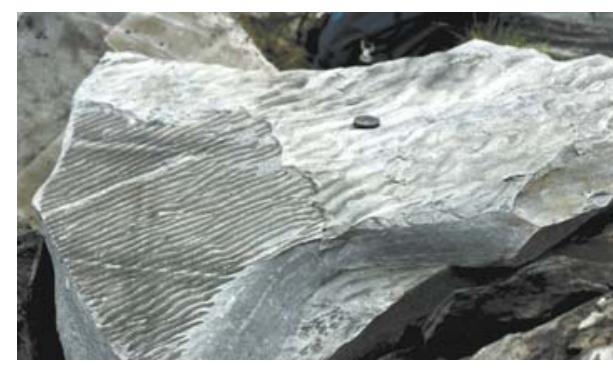

Rippled surface of a block of white quartzite from the Revett Formation. The thickest, cleanest quartzite beds in the formation were aquifers through which metalbearing brines moved and became hosts for coppersilver deposits. (USGS photograph by Tim Hayes.)

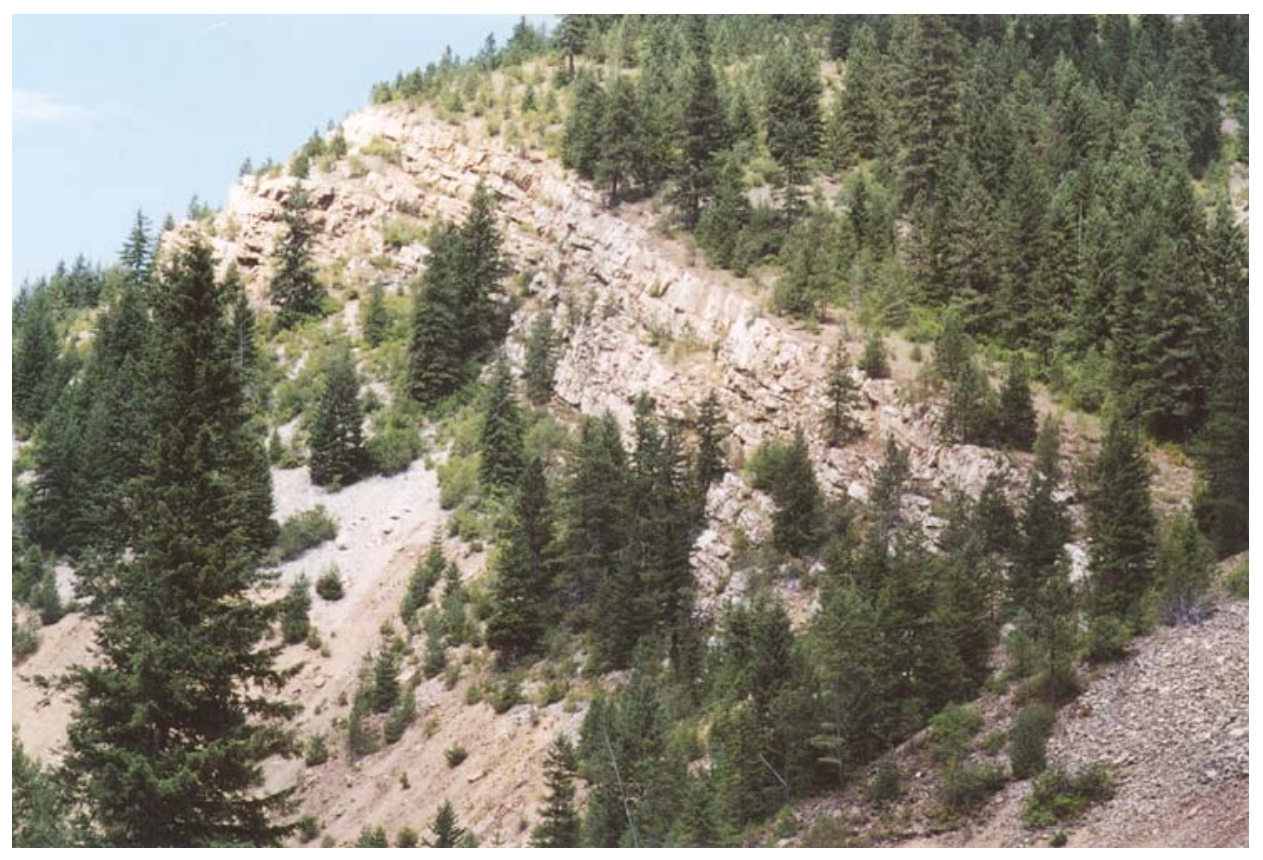

U.S. Geological Survey scientists recently completed an assessment of copper-silver deposits in the Revett Formation in northwestern Montana and northern Idaho. This photograph shows an outcrop of Revett Formation quartzite beds in the Coeur d'Alene Mining District of northern Idaho. (USGS photograph by Jeffrey Mauk.)

The Rock Creek-Montanore and Troy deposits, which are currently the most significant undeveloped resources identified in the western Montana copper belt, are among the Nation's largest stratabound copper-silver deposits, containing about 15 percent of the copper in such deposits in North America. Worldwide, stratabound copper-silver deposits contain 23 percent of all copper resources and are the secondmost important global source of the metal after porphyry copper deposits.

Production from the Revett Formation at the Troy Mine in Montana is 390 million pounds of copper and 48 million troy ounces of silver, and reserves are estimated to be 156 million pounds of copper and more than 18 million troy ounces of silver. Undeveloped resources at nearby Rock Creek-Montanore in Montana are estimated to be more than 5 billion pounds of copper and 679 million troy ounces of silver. Numerous other stratabound copper-silver prospects and occurrences in western Montana and northern Idaho were located as part of the USGS study, although few have had recorded production.

\section{Origin of the Copper-Silver Deposits}

The Revett Formation is part of the 1,401- to 1,470-million-year-old Belt Supergroup and was originally deposited during the Mesoproterozoic Era (1.6 to 1.0 billion years ago). The formation consists of quartzite, siltite, and argillite (very fine grained to medium-grained, quartz-rich metamorphosed sedimentary rocks). The thick, clean quartzites of the Revett Formation, which are among the coarsest-grained sedimentary rocks in the lower part of the Belt Supergroup, acted as aquifers before consolidation of the sediment into rock. Metals were deposited where oxidized metal-bearing brines upwelled along faults, migrated laterally through the aquifers, and intersected preexisting pyrite-hematite interfaces in the sediment, where the metals were reduced and deposited.

The deposits are characterized by mineral zones (characteristic ore and alteration 


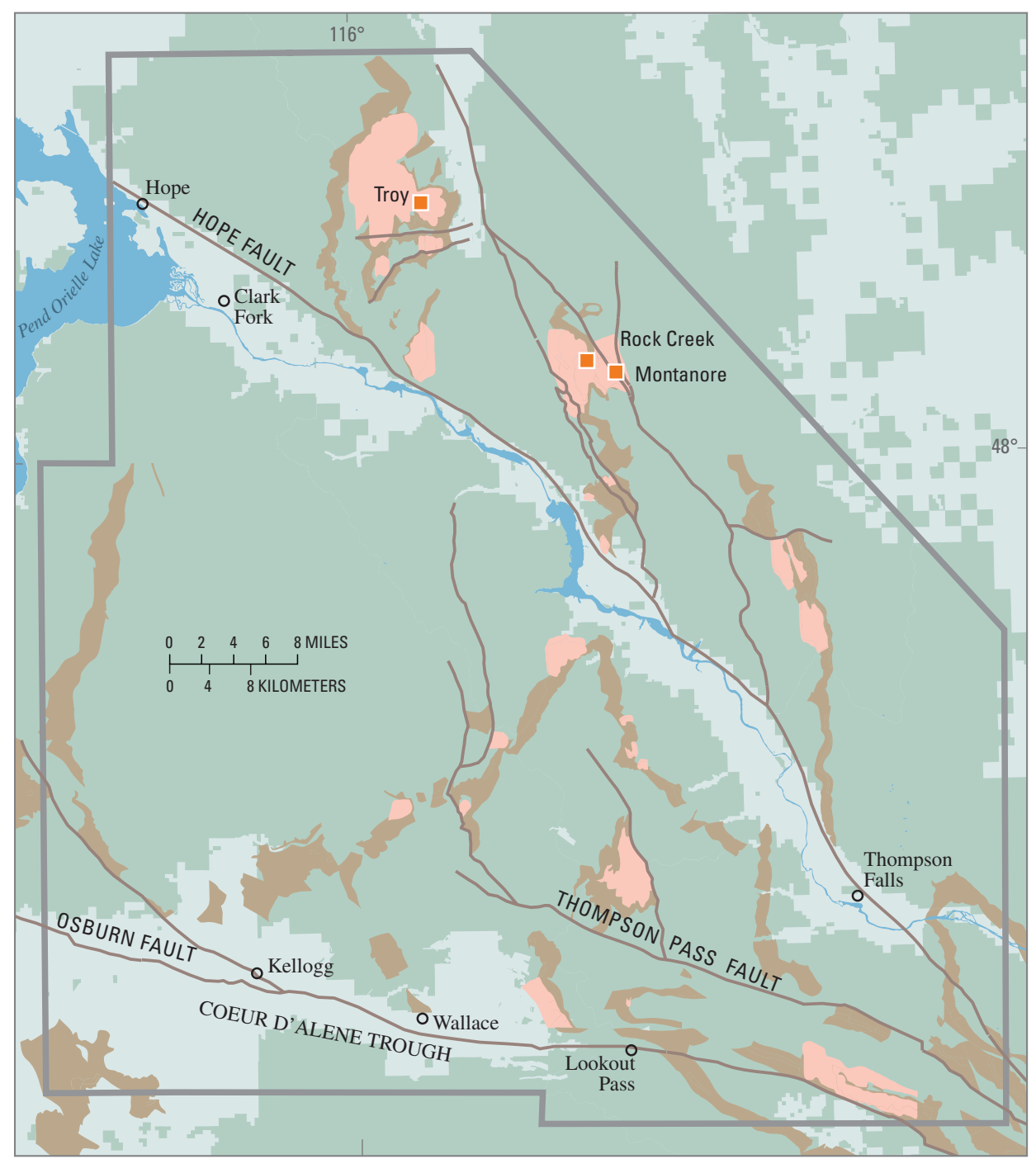

minerals) that provide a useful guide for exploration for mineral deposits. Regional changes in the mineral zones, the thickness and grain size of sedimentary beds, and the overall geologic structure provide evidence for the direction of fluid movement in the sediment during deposition of the Revett Formation and during formation of the copper-silver deposits and provide a framework to evaluate the potential for undiscovered deposits.

\section{Results of the USGS Assessment}

USGS scientists compiled and analyzed existing data on the distribution, stratigraphy, grain size, and primary and alteration mineralogy of the Revett Formation in western Montana and northern Idaho. The data-from 126 measured sections and diamond-drill holes, totaling more than 150,000 feet of true thickness-were made available by Asarco, Inc., and Kennecott Exploration, Inc., after abandoning exploration programs for Revett copper-silver deposits. The USGS assessment was then completed using these data plus descriptions of 57 Revett-type deposits and occurrences and geologic maps of the Revett Formation to determine areas permissive for the occurrence of other stratabound copper-silver deposits. This information is published as USGS Scientific Investigations Report 2005-5231 (http://pubs. usgs.gov/sir/2005/5231/) and is also documented in ArcInfo $®$ interchange files and spreadsheets to facilitate use in a geographic information system (GIS).

USGS scientists used the spatial distribution of copper-silver mineralization in the Revett Formation, as determined from an examination of measured sections and drill cores and an interpretation of the flow paths of brines in the sedimentary deposits, to conclude that approximately 556 square miles of mostly USFS-administered lands is favorable for undiscovered copper-silver deposits. These interpretations in the report will serve as a useful guide for future mineral-resource exploration and assist the USFS in land-use decisions

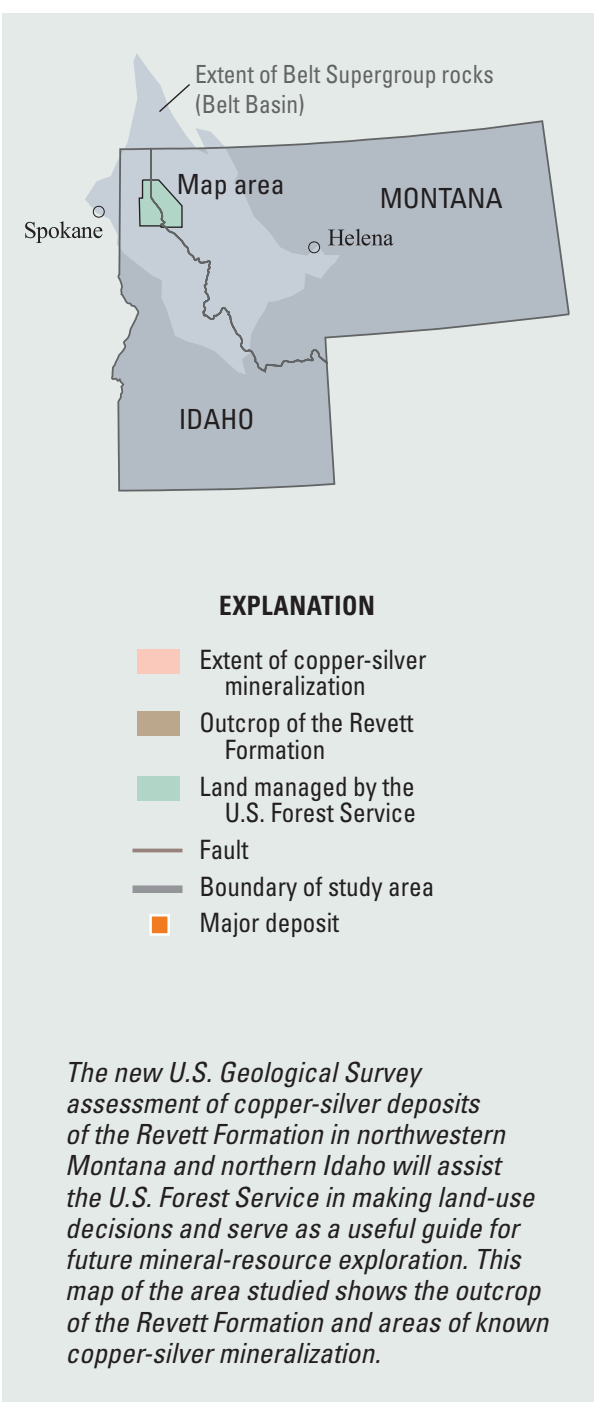

when mineral-resource development must be weighed against other land uses, such as recreation and habitat preservation.

Thomas P. Frost and Michael L. Zientek

Edited by James W. Hendley II and George Havach Graphic design by Susan Mayfield

\section{COOPERATING ORGANIZATION U.S. Forest Service}

$$
\begin{gathered}
\text { For more information, contact: } \\
\text { Thomas P. Frost } \\
\text { U.S. Geological Survey } \\
904 \text { W. Riverside Ave., Room } 202 \\
\text { Spokane, WA } 99201 \\
\text { (509) } 368-3103 \\
\text { http://minerals.usgs.gov/west/ }
\end{gathered}
$$

For the complete assessment see: Boleneus, D.E., Appelgate, L.M., Stewart, J.H., and Zientek, M.L., 2005, Stratabound copper-silver deposits of the Mesoproterozoic Revett Formation in Montana and Idaho, US Geological Survey Scientific Investigations Report SIR 2005-5231, 66 p., 3 map pls. [http://pubs.usgs.gov/sir/2005/5231/].

This Fact Sheet and any updates to it are available online at http://pubs.usgs.gov/fs/2006/3072/ 